\title{
Humeral shaft fractures and radial nerve palsy: early exploration findings
}

\author{
Humerus cisim kırıkları ve radial sinir felci: Erken eksplorasyon bulguları
}

\author{
Ali Çağdaş Yörükoğlu, MD., ${ }^{1}$ A. Fahir Demirkan, MD., ${ }^{1}$ Nihal Büker, ${ }^{2}$ \\ Alp Akman, MD., ${ }^{1}$ Nusret Ok, MD. ${ }^{1}$ \\ 'Department of Orthopedics and Traumatology, Medical Faculty of Pamukkale University, Denizli, Turkey \\ ${ }^{2}$ Department of Orthopaedic Physiotheraphy, School of Physical Theraphy and Rehabilitation, Pamukkale University, Denizli, Turkey
}

\begin{abstract}
Objectives: This study aims to present the results of early nerve explorations in cases with radial nerve palsy associated with humeral shaft fracture and to investigate in which cases early nerve explorations may be beneficial.

Patients and methods: Twenty-four patients (17 males, 7 females; mean age 36 years; range 18 to 72 years) with complete sensory and motor radial nerve damage associated with humeral shaft fracture were retrospectively analyzed. The patients with high-energy trauma and the ones who had spiral and segmental fractures with low energy traumas were included in the study. Early nerve exploration was performed in all patients within an average of 4.8 days (range 1 to 20 days) after fracture development. Electrophysiological assessments were performed in cases with no neurological recovery until $12^{\text {th }}$ week.
\end{abstract}

Results: Spiral fractures of the humerus shaft observed in $14(58.3 \%)$ of the 24 operated patients were the most common fracture type, followed by transverse fracture in four patients $(16.6 \%)$ and comminuted fracture in two patients (8.3\%). As a result of the exploration, we observed nerve compression between the fracture fragments in seven patients $(29.1 \%)$; a majority of these patients $(n=6)$ had spiral fractures of humerus and one patient had comminuted fracture. One patient with a spiral type fracture had nerve transection. Radial nerve function recovered in most of the patients (95.8\%). Average duration for fracture union was $6.7 \pm 3.8$ months (range 3 to 18 months).

Conclusion: Spiral fractures of humerus, particularly with wedge fragment, may be a candidate for early surgical exploration. Early exploration may be beneficial in terms of early identification of neural injury in patients with radial nerve dysfunction associated with spiral and comminuted humerus fracture.

Keywords: Humeral fracture, nerve contusion, peripheral nerve injuries, radial neuropathy.

\section{öz}

Amaç: $\mathrm{Bu}$ yazıda humerus cisim kırığıyla birliktelik gösteren radial sinir felçli olgularda erken dönem sinir eksplorasyonunun sonuçları sunuldu ve hangi olgularda erken sinir eksplorasyonunun faydalı olabileceği araştırıldı.

Hastalar ve yöntemler: Humerus cisim kırığına eşlik eden tam duyu ve motor radial sinir hasarı olan 24 hasta (17 erkek, 7 kadın; ort. yaş 36 yıl; dağılım 18-72 yıl) retrospektif olarak incelendi. Yüksek enerjili travmalı hastalar ile spiral ve parçalı kırı̆̆ı olan düşük enerjili travmalı hastalar çalışmaya alındı. Tüm hastalara sinir eksplorasyonu kırık oluşumu sonrası ortalama 4.8 günde (dağılım 1-20 gün) uygulandı. On ikinci haftaya kadar nörolojik iyileşme olmayan hastalara elektrofizyolojik değerlendirmeler uyguland.

Bulgular: Ameliyat edilen 24 hastanın 14'ünde (\%58.3) görülen spiral humerus cisim kırıkları en yaygın kırık tipi idi; bunu dört hastada transvers (\%16.6) ve iki hastada (\%8.3) parçalı kırık izledi. Eksplorasyon sonucu yedi hastada (\%29.1) sinirin kırık fragmanları arasında sıkışmış olduğu görüldü; bu hastaların çoğunluğu $(n=6)$ spiral humerus kırıklı idi, bir hastada ise parçalı kırık vardı. Spiral tip kırığı olan bir hastada sinir transeksiyonu vardı. Hastaların çoğunluğunda (\%95.8) radial sinir fonksiyonları iyileşti. Kırık kaynama süresi ortalama $6.7 \pm 3.8$ ay (dağılım 3-18 ay) idi.

Sonuç: Spiral humerus kırıkları, özellikle kama fragmanlı olanlar, erken cerrahi eksplorasyon için aday olabilir. Erken dönem eksplorasyonu spiral ve parçalı humerus kırığına eşlik eden radial sinir disfonksiyonlu hastalarda sinir hasarının erken saptanması açısından faydalı olabilir.

Anahtar sözcükler: Humerus kırığı, sinir ezilmesi, periferik sinir hasarları, radial nöropati.

- Received: July 14, 2015 Accepted: December 12, 2015

- Correspondence: A. Fahir Demirkan, MD. Pamukkale Üniversitesi Tıp Fakültesi Ortopedi ve Travmatoloji Anabilim Dalı, 20070 Kınıklı, Denizli, Turkey. Tel: +90 258 - 4440728 / 5668 Fax: +90 258 - 2131034 e-mail: fahirdemirkan@yahoo.com 
Humeral fractures are problematic in all ages. ${ }^{[1,2]}$ The incidence of radial nerve injuries with humerus fractures has been documented to be between $2 \%$ to $25 \% .{ }^{[3,4]}$ The nerve may be injured due to contusion, laceration, traction or entrapment between the fracture fragments. ${ }^{[4]}$ Potential advantages of early exploration of a radial nerve palsy following a closed fracture of the humerus are immediate fracture stabilization and earlier rehabilitation, less muscular atrophy and endplate loss, and earlier return to function. ${ }^{[4]}$ In this article, we aimed to present the results of early nerve explorations in cases with radial nerve palsy associated with diaphyseal fracture of the humerus and to investigate in which cases early nerve explorations may be beneficial.

\section{PATIENTS AND METHODS}

Twenty-four patients (17 males, 7 females; mean age 36 years; range 18 to 72 years) treated surgically for humeral shaft fracture with radial nerve palsy at Pamukkale University Hospital between March 2006 and March 2014 were included in this retrospective analysis. Early explorations were performed in all patients who underwent surgery within 4.8 days after the injury (range 1 to 20 days). The mean followup time was 32 months (range 14-120 months). The series contained 24 traumatic fractures which were classified according to the AO (Arbeitsgemeinschaft für Osteosynthesefragen) classification. The study protocol was approved by the Ethics Committee of Pamukkale University Faculty of Medicine. Written informed consent was obtained from each patient, and the study was conducted in accordance with the principles of the Declaration of Helsinki.

Modified non triceps splitting approach was used where the triceps muscle is retracted medially to expose the radial nerve, proximal to its piercing of the intermuscular septum. After exploration of the nerve, either plate fixation or intramedullary nail is used to fix the fracture.

No cast or brace was used postoperatively. Shoulder and elbow range of motion (ROM) was initiated at postoperative first day. The degrees of shoulder forward flexion, abduction, and elbow extension and flexion were evaluated with a universal goniometer. Visual analog pain scale (vertical, $10 \mathrm{~cm}$ ) was used. Third month after surgery, the Disabilities of the Arm, Shoulder and Hand Questionnaire (Turkish version) was used to assess the upper extremity functional level. Jamar hydrolic hand dynamometer (Lafayette Instrument Company, Lafayette, IN, USA) was used to measure grip force. Clinical assessment after fracture healing was performed according to
Hunter's criteria. ${ }^{[5]}$ The patients were followed-up by routine clinical examination for nerve recovery. Electrophysiological assessment was conducted in cases with no neurological recovery until $12^{\text {th }}$ week.

Data were analyzed using the SPSS version 16.0 (SPSS Inc., Chicago, IL, USA). Descriptive statistics (means, frequencies, and standard deviation) were used to describe characteristics of humeral fractures.

\section{RESULTS}

Twenty patients $(83.3 \%)$ sustained injury as a result of high-energy trauma, while four patients $(16.6 \%)$ had humerus shaft fracture due to low-energy trauma. All patients were right-hand dominant. While right humerus was injured in $58.3 \% \quad(n=14)$, left humerus was injured in $41.6 \%(\mathrm{n}=10)$.

Seven fractures $(29.1 \%)$ occurred in the middle one third, $13(54.1 \%)$ in the distal one third of the shaft of the humerus, and the remaining two $(83 \%)$ in the proximal one third of the shaft. Two patients $(8.3 \%)$ had segmental fractures, involving both the middle and distal thirds of the humerus. Seven fractures had no comminution, 15 patients had comminuted fracture involving a wedge fragment, and two patients had significant comminution or bone loss. Three patients had open fractures.

Spiral fractures of the humerus shaft were by far the most common; of the 24 operated patients, $14(58.3 \%)$ had this type, followed by transverse fracture in four patients $(16.6 \%)$ and comminuted fracture in two patients $(8.3 \%)$ (Figure 1, 2). Of the remaining patients, two had fragmented wedge, one had bending wedge, and one had oblique fracture. Fractures were classified according to the $\mathrm{AO}$ classification system (Table 1).

At exploration, nerve compression between the fragments were found in seven patients (29.1\%), more often with spiral fractures of humerus (6 cases including 5 B1 and 1 A1) (Figure 3a, b). One patient with nerve injury had comminuted fracture (C3). Only one of the 24 (4\%) explored patients had nerve transection. Transected nerve was repaired primarily using a microscope. In $68 \%$ of all cases, the nerve was slightly to moderately bruised. The recovery was complete in 12 weeks (range 8 to 24 weeks). Signs of recovery were delayed for eight months in one patient. Radial nerve functions returned in all patients except one. Radial nerve entrapment in fracture callus was identified during second exploration in the patient whose nerve functions had not returned at one year follow-up. Tendon transfer was performed on that patient. 

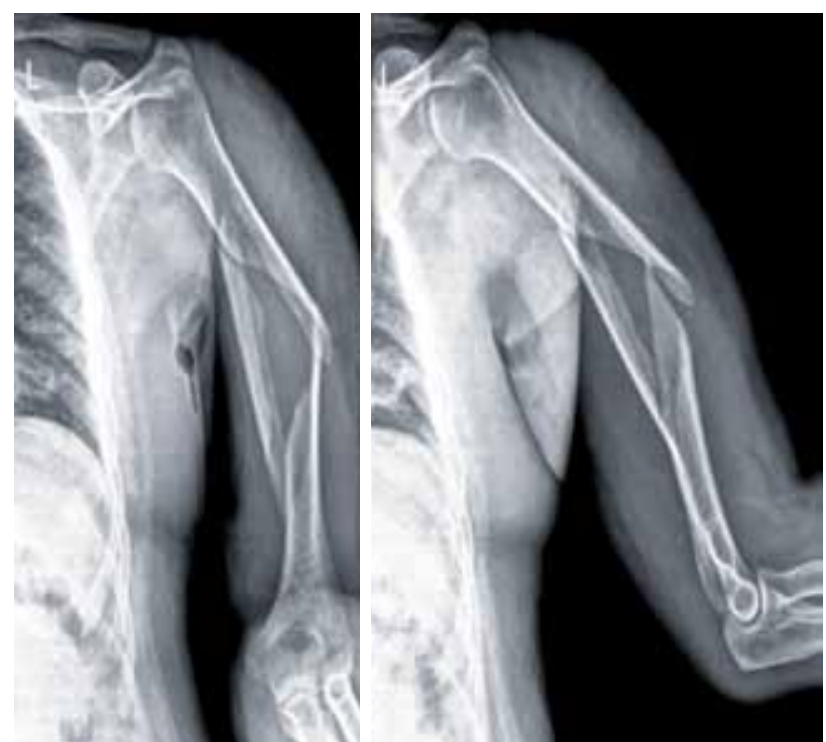

Figure 1. Preoperative X-ray with nerve entrapment.

Average time to union was $6.7 \pm 3.8$ months (range 3 to 18 months). Healing was delayed in two cases with comminuted fractures. An assessment of functional outcome by Hunter criteria revealed small impairment in daily activities because of restricted movement in eight patients (22.9\%) (Hunter G3), mild restriction in movement not affecting daily activities in 11 patients (314\%) (Hunter G4), and full ROM in shoulder and elbow (Hunter G5) in 16 patients (45.7\%). Range of motion of the affected extremity was not statistically significantly different from the unaffected side (Table 2). There were no significant differences in terms of grip force between the injured and uninjured extremities $(\mathrm{p}=0.451)$.

\section{DISCUSSION}

The appropriate management of radial nerve dysfunction in closed humeral shaft fracture is still

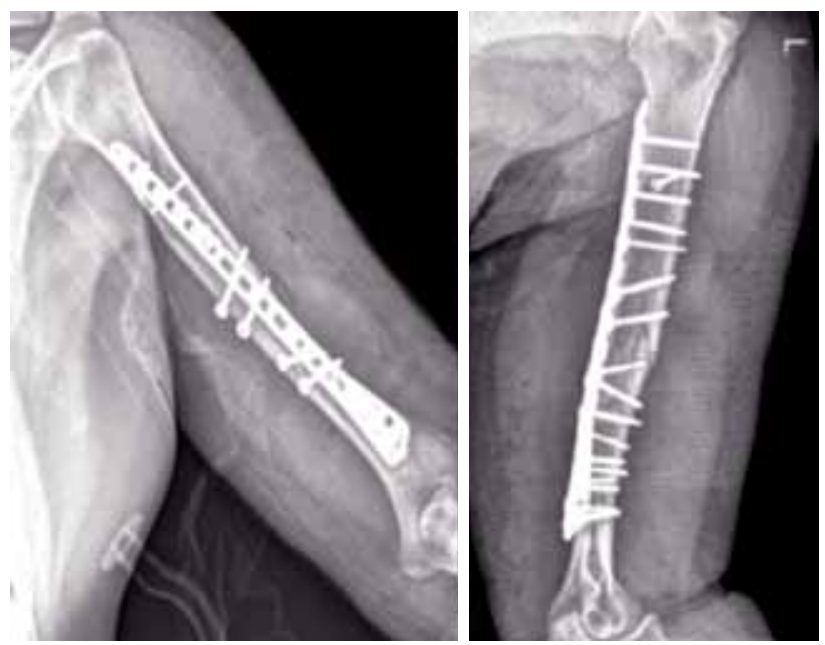

Figure 2. Postoperative X-ray; internal fixation with a medial distal tibial plate.

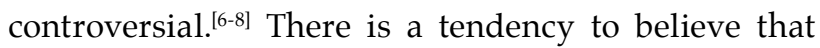
these injuries do not require early exploration and their observation is appropriate..$^{[9]}$ On the other hand, some continue to consider immediate exploration of closed injuries if there is a high-energy injury mechanism. ${ }^{[10]}$ Advocates of early exploration of radial nerve suggest that there are potential advantages which may be listed as follows; (i) it is technically easier and reliable, (ii) examining the nerve clarifies the extent of the lesion, thus facilitating neurorrhaphy, (iii) shortening of the bone may permit primary nerve repair, (iv) stability of the fracture may protect the radial nerve from further trauma, and (v) the damaged nerve can be separated from the developing scar tissue or callus. ${ }^{[1]]}$ The extent of the nerve injury might vary from a mild bruise to severe crush, entrapment or laceration. Accurate visualization of the injured nerve may help to shorten the time gap between injury and treatment. Early repairs are more

TABLE I

Classification of 24 fractures of humeral shaft according to $\mathrm{AO}$ system

\begin{tabular}{lcccc}
\hline Fracture type & Type of AO classification & Number & Entrapped nerve & Injured nerve \\
\hline Spiral & A1 & 1 & 1 & - \\
& B1 & 10 & 5 & - \\
Transverse & C1 & 3 & - & 1 \\
Comminuted & A3 & 4 & - & - \\
Wedge & C3 & 2 & 1 & - \\
& B3 & 2 & - & - \\
Oblique & B2 & 1 & - & - \\
Total & A2 & 1 & - & 1 \\
\hline
\end{tabular}

AO: Arbeitsgemeinschaft für Osteosynthesefragen. 


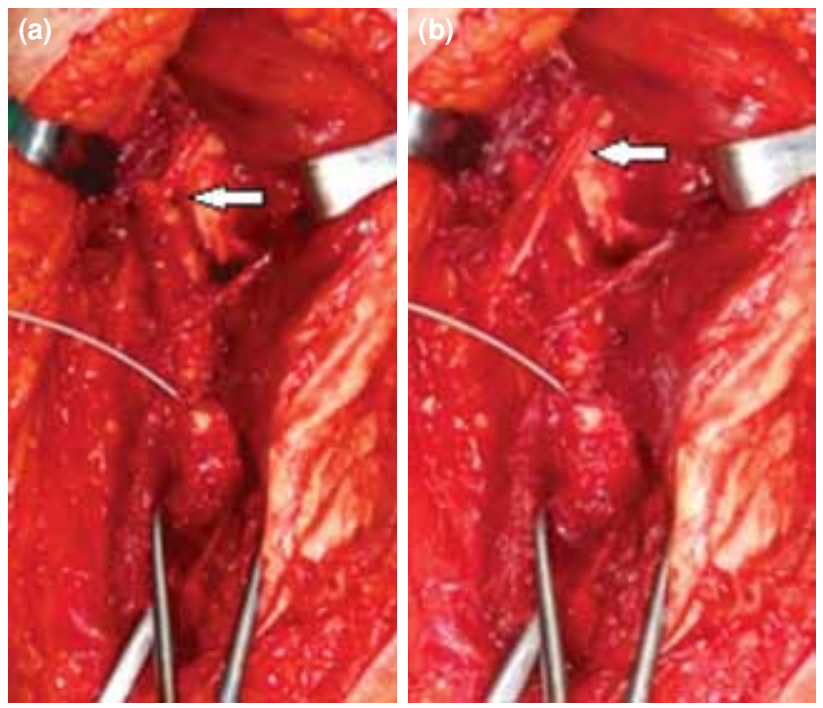

Figure 3. (a) Proximal and varus displacement of spiral fracture of humerus led to entrapment of nerve at fracture site (radial nerve is indicated with an arrow). (b) Surgical decompression of nerve resulted in neurological recovery (radial nerve is indicated with an arrow).

efficient than late repairs. ${ }^{[12]}$ Spontaneous recovery of neural functions after conservative management in some series has been reported as $70 \% \cdot{ }^{[9,13,14]}$ Also, at early exploration, some authors found the nerve either lacerated or interposed between fragments to be as high as $47 \% .{ }^{[14,15]}$ These findings indicate that early exploration may be beneficial in a significant number of the cases.

Advocates of late exploration restricts surgery to cases without spontaneous nerve recovery at three to six months, recommend 16 to 18 weeks of expectant management and nerve repair to be performed no later than seven months after injury. ${ }^{[16]}$ An average duration from injury to recovery may be up to eight to nine months due to waiting period in late exploration. Factors that influence the outcome after grafting include the length of the defect that should be bridged and the denervation time. ${ }^{[16]}$ In our study, the lacerated nerve $(4.1 \%)$ was repaired end to end with no delay, preventing the gap formation that necessitates another incision for sural nerve graft. Seddon et al. ${ }^{[17]}$ reported the importance of reducing the interval between injury and repair. Thus, prolonged denervation after delayed nerve repair is detrimental to functional recovery and accounts for a $90 \%$ reduction in the number of functional motor units. ${ }^{[18]}$ This condition might lead to increased morbidity. Delaying the exploration might also cause the degeneration of the nerve in cases with entrapment which is seen in $29 \%$ of the cases.
TABLE II

Range of motion, pain and functional level

\begin{tabular}{lcc}
\hline Variables & Min.-Max. & Mean \pm SD \\
\hline Shoulder & & \\
Flexion & $145-180$ & $170.6 \pm 14.7$ \\
Extension & $32-45$ & $42.8 \pm 5.7$ \\
Abduction & $98-180$ & $159.1 \pm 31.8$ \\
Internal rotation & $45-90$ & $78.6 \pm 18.1$ \\
External rotation & $50-90$ & $81.2 \pm 16.0$ \\
Elbow & & \\
Flexion & $70-145$ & $123.9 \pm 29.3$ \\
Extension & $-20-0$ & $-3.3 \pm 7.1$ \\
Pain(VAS) & & \\
Rest & $0-5.5$ & $1.4 \pm 2.5$ \\
Activity & $0-7.5$ & $3.2 \pm 1.9$ \\
DASH-T & $18-82$ & $28.9 \pm 24.0$ \\
\hline
\end{tabular}

Min.: Minimum; Max.: Maximum; SD: Standard deviation; VAS: Visual analog scale; DASH-T: Disabilities of the Arm, Shoulder and Hand.

Experimental studies have demonstrated poor functional recovery when nerve repair is delayed for three months due to decreased motor neuron regeneration capacity. ${ }^{[18]}$ An injured peripheral nerve has to be treated within six months to regain an optimal functional outcome; otherwise, irreversible muscle atrophy may occur due to degeneration of the motor endplate. ${ }^{[19]}$ Muscle atrophy begins immediately after denervation and $60 \%$ to $80 \%$ of muscle volume may be lost at four months. ${ }^{[1]]}$ In another study, after delayed repair of more than four months, regeneration declined to approximately $33 \%$ of the number of axons that could regenerate after an immediate nerve repair. ${ }^{[20]}$ We believe that early repair is technically easier and has superior outcomes compared with delayed repair.

It has been reported that ROM was decreased by more than 10 degrees in the shoulder ( $40 \%$ of cases) and elbow (24\% of cases) when functional bracing was used. ${ }^{[21]}$ Sarmiento et al. ${ }^{[22]}$ reported less than 15 degrees of abduction and rotation loss in nine of 49 patients at the time of sleeve removal. No brace or cast was used in our patients, thus they had better ROM. Importantly, patients were operated on early and their fractures were given enough stability to allow early ROM exercise; therefore, shoulder and elbow joints had no time to freeze.

Literature search revealed that transverse (21.2\%) and spiral fractures (19.8\%) had a significantly higher occurrence of radial nerve palsy $(\mathrm{p}<0.001)$ than oblique $(8.4 \%)$ and comminuted fractures $(6.8 \%)$. In our series, the nerve was entrapped between 
fragments in seven of the patients who underwent surgical nerve exploration. In six patients, the type of fracture was spiral (according to AO classification, $6 \mathrm{~B} 1$ and $1 \mathrm{~A} 1)$ and the remaining one patient had a comminuted fracture (C3). There was also a spiral type of the fracture (C1) in the patient with nerve laceration. In half of the patients with spiral fractures with wedge fragment, the nerve was entrapped between fragments (Figure 1). Thus, we suggest that spiral fractures, particularly spiral fractures with a wedge fragment, may be a candidate for early surgical exploration.

The limitation of our study is the lack of another group with late nerve exploration and a conservative treatment group. In conclusion, early exploration might be beneficial in terms of early identification of neural injury since severe and permanent damage to the radial nerve due to laceration or gross impingement by displaced bone fragments, scar tissue, or callus might be prevented in radial nerve dysfunction with spiral and comminuted humerus fractures. There was a recovery in radial nerve function in most of the cases in our series (95.8\%) after surgical fixation of the fracture. Early exploration may be advantageous, particularly in spiral fractures (A1, B1, and C1) for early return to a functional life, may diminish the risk of restriction in $\mathrm{ROM}$, and enhance a more complete and constant functional recovery.

\section{Declaration of conflicting interests}

The authors declared no conflicts of interest with respect to the authorship and/or publication of this article.

\section{Funding}

The authors received no financial support for the research and/or authorship of this article.

\section{REFERENCES}

1. Ekholm R, Adami J, Tidermark J, Hansson K, Törnkvist $\mathrm{H}$, Ponzer S. Fractures of the shaft of the humerus. An epidemiological study of 401 fractures. J Bone Joint Surg Br 2006;88:1469-73.

2. Turgut A, Kalenderer Ö, Bozoğlan M, Bacaksız T, Ağuş $\mathrm{H}$. Flexion type supracondylar humerus fractures: 12 year experience of a pediatric orthopedics clinic. Eklem Hastalik Cerrahisi 2015;26:151-7.

3. Larsen LB, Barfred T. Radial nerve palsy after simple fracture of the humerus. Scand J Plast Reconstr Surg Hand Surg 2000;34:363-6.

4. Niver GE, Ilyas AM. Management of radial nerve palsy following fractures of the humerus. Orthop Clin North Am 2013;44:419-24.

5. Hunter SG. The closed treatment of fractures of the humeral shaft. Clin Orthop Relat Res 1982;164:192-8.

6. Venouziou AI, Dailiana ZH, Varitimidis SE, Hantes ME, Gougoulias NE, Malizos KN. Radial nerve palsy associated with humeral shaft fracture. Is the energy of trauma a prognostic factor? Injury 2011;42:1289-93.

7. DeFranco MJ, Lawton JN. Radial nerve injuries associated with humeral fractures. J Hand Surg Am 2006;31:655-63.

8. Bishop J, Ring D. Management of radial nerve palsy associated with humeral shaft fracture: a decision analysis model. J Hand Surg Am 2009;34:991-6.

9. Lowe JB, Sen SK, Mackinnon SE. Current approach to radial nerve paralysis. Plast Reconstr Surg 2002;110:1099-113.

10. Ring D, Chin K, Jupiter JB. Radial nerve palsy associated with high-energy humeral shaft fractures. J Hand Surg Am 2004;29:144-7.

11. Holstein A, Lewis GM. Fractures of the humerus with radial-nerve paralysis. J Bone Joint Surg [Am] 1963;45:1382-8.

12. Lee SK, Wolfe SW. Peripheral nerve injury and repair. J Am Acad Orthop Surg 2000;8:243-52.

13. Shao YC, Harwood P, Grotz MR, Limb D, Giannoudis PV. Radial nerve palsy associated with fractures of the shaft of the humerus: a systematic review. J Bone Joint Surg Br 2005;87:1647-52.

14. Ljungquist KL, Martineau P, Allan C. Radial nerve injuries. J Hand Surg Am 2015;40:166-72.

15. Nooman H, Khalifa AR, El-Deen MA, Shiha A. Early surgical exploration of radial nerve injury associated with fracture shaft humerus. Microsurgery 2008;28:635-42.

16. Korompilias AV, Lykissas MG, Kostas-Agnantis IP, Vekris $\mathrm{MD}$, Soucacos PN, Beris AE. Approach to radial nerve palsy caused by humerus shaft fracture: is primary exploration necessary? Injury 2013;44:323-6.

17. Seddon HJ, Medawar PB, Smith H. Rate of regeneration of peripheral nerves in man J Physiol 1943;102:191-215.

18. Fu SY, Gordon T. Contributing factors to poor functional recovery after delayed nerve repair: prolonged denervation. J Neurosci 1995;15:3886-95.

19. Bodner G, Buchberger W, Schocke M, Bale R, Huber B, Harpf $C$, et al. Radial nerve palsy associated with humeral shaft fracture: evaluation with US--initial experience. Radiology 2001;219:811-6.

20. Wiertz-Hoessels EL, Krediet P. Degeneration of the motor end-plates after neurectomy, in the rat and the rabbit. Acta Morphol Neerl Scand 1965;6:179-93.

21. Kobayashi M, Watanabe $Y$, Matsushita T. Early full range of shoulder and elbow motion is possible after minimally invasive plate osteosynthesis for humeral shaft fractures. J Orthop Trauma 2010;24:212-6.

22. Sarmiento A, Kinman PB, Galvin EG, Schmitt RH, Phillips JG. Functional bracing of fractures of the shaft of the humerus. J Bone Joint Surg [Am] 1977;59:596-601. 